\title{
Depression Post-Hospitalization in Elderly Patients: a Systematic Review \\ REVIEW
}

Laryssa leal da Cruz Macedo, Rebeca Alves de Freitas e Albuquerque ${ }^{1}$, José Mozart Ribeiro Neto

\section{Abstract}

Focusing on depression in elderly patients, a qualitative systematic review of articles about depression in hospitalized aged people was realized on a basis of preselected data. A search of the literature was performed from the online database SCOPUS from January, 2009 to June, 2015. The search was focused from the following terms: 1. 'Aged' (Medical Subject Headings) [MeSH term]; 2. 'Hospitalization' (Medical Subject Headings) [MeSH term]; and 3. 'Depression' [MeSH term]. The choice of these terms was made from a careful conciliation, which applied to define our central matter of the article based on requested descriptors. Thus, the articles were evaluated with rigor to guarantee proper sampling.

\section{Keywords}

Depression Post-hospitalization; Elderly Patients; Systematic Review.

\section{Introduction}

The process of aging is a complex combination of chronological, functional and social changes. Most countries accept the definition of old person the age of 65 years, although the United Nations (UN) does not define a rule criteria, it's agreed a cutoff of $60+$ years to refer to the older population, and the oldest old as $85+$. The proportion of elderly people is growing faster than any other age group, and in accordance to Nagga et al (2012) [1] one inescapable result is the great quantity of chronic diseases and the relative necessity for medical care.

The older patients have increased chance of unfavorable outcomes in hospitalization; following the reasoning of Nagga et al (2012) [1] this includes prolonged hospital stay, nursing home placement, functio- 
nal decay and premature death $[2,3,4]$. And it is known that elderly admitted to hospital for an acute welfare problem are at risk of functional decline after hospital discharge [5].

Hospitalization increases depressive symptoms in older adults, for Haines et al (2015) [2] the risk of experiencing those symptoms is increased by cognitive impairment, illness and limited access to friends and family support networks. The predominance of it is $50 \%$ among hospitalized older adults, yet is known to be lower some months after hospital discharge [6], yet other studies affirms the range of symptoms is from $1.6 \%$ to $19 \%$ with patients accompanied for 6 to 12 months [7]. Accordingly to Unsar and Sut (2010) [4] depression is the most common emotional question in this group, it causes disability of functional impairment, decreased QOL (quality of life) and has a negative effect on the physiological recovery from illness.

Elevated levels of depressive symptoms are associated with bad treatment adhesion, longer stays, more hospital readmissions, and reduced functional status, inattentive of their comorbidities [8]. Those symptoms of hospital-related depression have a dynamic nature at different time-points: admission, discharge and post-discharge in accordance to Ciro et al (2012) [6].

The prevalence of depression is valued to be higher in those being in hospitals and living with health problems compared with the general population of elderly people [9], it is a multifaceted disease with age-dependent presentation of symptoms [10]. McKenzie et al (2010) [11] exemplifies several proportions of mood states, including hopelessness, helplessness and anhedonia (cannot experience pleasure), although it affirms that the frontier between clinical depression and normal sadness, as consequence of infirmity or hospital stay, is foggy. To Nagga et al (2012) [1], 36\% of the elderly population report worries such as fear of diseases, of becoming dependent, relatives' health, loneliness and an uncertain future.
It is defined by Ciro et al (2012) [6] that female, white, unmarried patient, or the ones with lower social support and higher activities of daily living $(A D L)$ were denotatively more likely to have higher depressive symptoms. But the relationship between specific diseases, depressive symptoms and hospitalization needs further inquiry [8].

This review, in the aim to fulfill the goal of geriatric medicine (reducing morbidity and mortality, preventing hospital admission/readmission, postponing institutionalization and enhancing health-related quality of life), proposes to clarify the post-hospitalization depression in elderly patients knowing that the early detection permits to prevent the progress or deterioration of the depressive symptoms. We identify the risk groups, the prevalent symptoms and the valid approach that will most likely have a positive effect in those patients.

\section{Methods}

Focusing on depression in elderly patients, a qualitative systematic review of articles about depression in hospitalized aged people was realized on a basis of preselected data. A search of the literature was performed from the online database SCOPUS from January, 2009 to June, 2015. The search was focused from the following terms: 1. 'Aged' \{Medical Subject Headings\} [MeSH term]; 2. 'Hospitalization' \{Medical Subject Headings\} [MeSH term]; and 3. 'Depression' [MeSH term].

The choice of these terms was made from a careful conciliation, which applied to define our central matter of the article based on requested descriptors. Thus, the articles were evaluated with rigor to guarantee proper sampling.

The analysis of the articles obeyed predefined eligibility criteria. We adopt the following inclusion criteria: (1) Original articles with full text online access; (2) From the relevant source title: "Journal of Affective Disorders", "Psychosomatics", "Journal of Clinical Psychiatry" and "Archives of Gerontology 
and Geriatrics"; (3) Observational, experimental or quasi-experimental studies; (4) Writings in English only; (5) Studies which focus on the depressive symptoms in elderly patients after hospitalization.

Exclusion criteria were: (1) Other projects, such as case reports, case series, literature review and comments, (2) The non-original studies, including editorials, comments, prefaces, brief comments and letter to the editor; (3) Productions that did not address depression and the hospitalized old patients; and (4) the articles in which the objective of the study did not matched the theme purposed by the systematic review in question.

We found applicable 197 articles that, when screened, resulted in 20 articles that met the criteria of evidence and were included in this review.

(Fig.1) (Table. 1)

\section{Discussion}

\section{The aging process and its hospitalization} causes and consequences

The last few decades of medicine have been marked by the increase of attention with aged pa- tients, the field of Geriatric Medicine has improved innumerous protocols and treatment approaches for its specific group. The fast demographic change came with lots of questions to health care systems due to special characteristics of elderly, been important to define the elements that contribute to better results of hospitalization and treatment $[12,13]$.

The most common and significant health problem of old people are the chronic diseases related with heart, cancer, cerebrovascular, respiratory system, endocrine, infections, renal, liver and rheumatic diseases [4]. Nagga et al (2012) [1] assumes that $85 \%$ of the population have one or several chronic diseases, the greater number being related to the cardiovascular system, in decreasing order of frequency: hypertension (50\%), hyperlipidemia (22\%) and congestive heart failure (15\%).

A new medical term, with ascendant popularity, "geriatric syndromes" referent to medical conditions of the old, such as dementia, falls, malnutrition and weight loss, losses in activity of daily living, cognitive dysfunction, sensory loss, delirium, urinary incontinence, dizziness, pain, osteoporosis, substance abuse, depression, iatrogenic problems,

Figure 1: Flow chart showing study selection for the review.

\section{SCOPUS}

MeSh TERMS: aged, hospi-

talization, depression

Full text in english

2009 - Present

Original articles

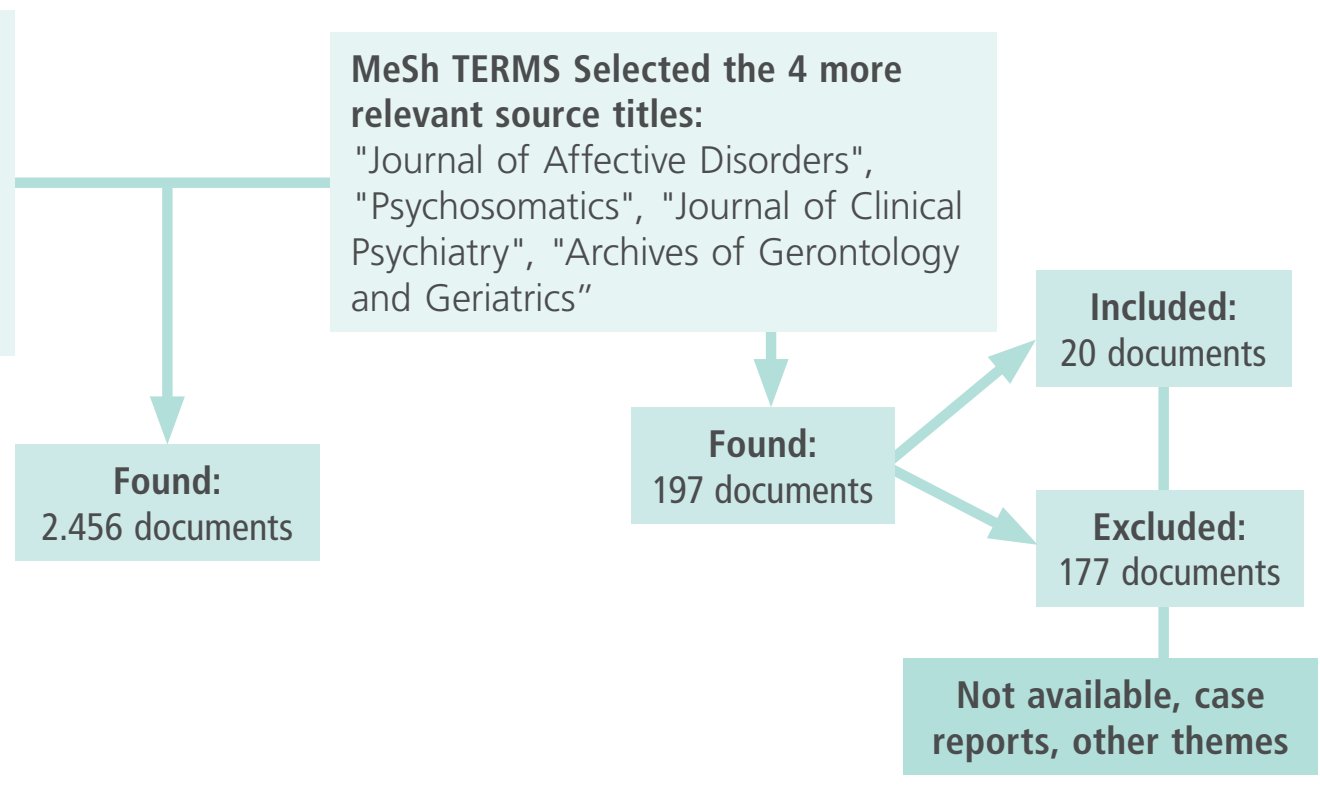


Table 1. Studies and main finding.

\begin{tabular}{|c|c|c|c|c|}
\hline Journal & Sample & $\begin{array}{c}\text { Study } \\
\text { Particularities }\end{array}$ & Study Particularities & Study Particularities \\
\hline $\begin{array}{l}\text { Haines, } \\
\text { T.P et al, } \\
2015\end{array}$ & $\begin{array}{l}\text { Depressive symptoms } \\
\text { and adverse outcomes } \\
\text { from hospitalization in } \\
\text { older adults: Secondary } \\
\text { outcomes of a trial of falls } \\
\text { prevention education }\end{array}$ & $\begin{array}{l}\text { Archives of } \\
\text { Gerontology } \\
\text { and Geriatrics }\end{array}$ & $\begin{array}{l}\text { Participants ( } n=1206) \text { were older adults } \\
\text { admitted within two Australian hospitals, } \\
\text { the majority of participants completed the } \\
\text { Geriatric Depression Scale - Short Form } \\
\text { (GDS) at admission ( } n=1168) \text {. Participants' } \\
\text { mean age was } 74.7( \pm \text { SD 11) years and } \\
47 \%(n=551) \text { were male. }\end{array}$ & $\begin{array}{l}\text { The only factor other than admission level of depression that affected } \\
\text { depressive symptoms change was if the participant was worried about } \\
\text { falling. Older patients frequently present with symptoms of clinical } \\
\text { depression on admission to hospital. Future research should consider } \\
\text { these factors, whether these are modifiable and whether treatment may } \\
\text { influence outcomes. }\end{array}$ \\
\hline $\begin{array}{l}\text { Chen, C.-M., } \\
\text { Huang, } \\
\text { G.-H., } \\
\text { Chen, C.C.H, } \\
\text { 2014 }\end{array}$ & $\begin{array}{l}\text { Older patients' depressive } \\
\text { symptoms } 6 \text { months } \\
\text { after prolonged } \\
\text { hospitalization: Course } \\
\text { and interrelationships with } \\
\text { major associated factors }\end{array}$ & $\begin{array}{l}\text { Archives of } \\
\text { Gerontology } \\
\text { and Geriatrics }\end{array}$ & $\begin{array}{l}\text { For this study, we conducted a secondary } \\
\text { analysis of data from a prospective cohort } \\
\text { study of } 351 \text { patients aged } 65 \text { years and } \\
\text { older. }\end{array}$ & $\begin{array}{l}\text { Depressive symptoms at discharge showed significant cross-lagged } \\
\text { effects on functional dependence and nutritional status at } 6 \text { months } \\
\text { after discharge, suggesting a reciprocal, triadic relationship. Thus, } \\
\text { treating one condition might improve the other. Targeting the triad of } \\
\text { depressive symptoms, functional dependence, and nutritional status, } \\
\text { therefore, is essential for treating depressive symptoms and improving } \\
\text { the overall health of older adults hospitalized for acute illness. }\end{array}$ \\
\hline $\begin{array}{l}\text { Helvik, A.-S., } \\
\text { Selbæk, G., } \\
\text { Engedal, K. } \\
\quad 2013\end{array}$ & $\begin{array}{l}\text { Functional decline in older } \\
\text { adults one year after } \\
\text { hospitalization }\end{array}$ & $\begin{array}{l}\text { Archives of } \\
\text { Gerontology } \\
\text { and Geriatrics }\end{array}$ & $\begin{array}{l}\text { The study included } 363 \text { (175 men) } \\
\text { medical inpatients with age range } 65-98 \\
\text { (mean } 80.2, \text { SD } 7.5 \text { ) years. For the total } \\
\text { sample, the mean P-ADL was significantly } \\
\text { worsened from T1 to T2 (mean change } 0.5 \text {, } \\
\text { SD 2.8; } p<0.01 \text { ). }\end{array}$ & $\begin{array}{l}\text { In conclusion, worse P-ADL at T2 was, independently of age and } \\
\text { baseline P-ADL, associated with impaired cognitive function and QOL } \\
\text { related to physical ability at baseline, as well as worsening depression, } \\
\text { cognition and QOL from T1 to T2. Our findings highlight the importance } \\
\text { of applying results from screening measures of cognitive function } \\
\text { and emotional health when planning care for older people after } \\
\text { hospitalization. }\end{array}$ \\
\hline $\begin{array}{l}\text { Wilkowska- } \\
\text { Chmielewska, } \\
\text { J., Szelenber- } \\
\text { ger, W., Woj- } \\
\text { nar, M. } 2013\end{array}$ & $\begin{array}{l}\text { Age-dependent } \\
\text { symptomatology of } \\
\text { depression in hospitalized } \\
\text { patients and its } \\
\text { implications for DSM-5 }\end{array}$ & $\begin{array}{l}\text { Journal of } \\
\text { Affective } \\
\text { Disorders }\end{array}$ & $\begin{array}{l}\text { The study entailed medical records of } 326 \\
\text { inpatients diagnosed with major depressive } \\
\text { disorder, including } 520 \text { depressive episodes, } \\
\text { with } 113 \text { first episodes lifetime. }\end{array}$ & $\begin{array}{l}\text { Age and age at onset are important factors influencing the course } \\
\text { and symptomatology of a depressive episode. Depressive episodes } \\
\text { with anxiety and with suicide risk severity are important specifiers that } \\
\text { vary with the age at onset and/or age of the patient and should be } \\
\text { considered for inclusion in the DSM-5 revision. }\end{array}$ \\
\hline
\end{tabular}




\begin{tabular}{|c|c|}
\hline Journal & Sample \\
\hline $\begin{array}{c}\text { Helvik, A.-S., } \\
\text { Engedal, K., } \\
\text { Selbæk, G, } \\
2013\end{array}$ & $\begin{array}{l}\text { Change in sense of } \\
\text { coherence (SOC) and } \\
\text { symptoms of depression } \\
\text { among old non-demented } \\
\text { persons } 12 \text { months after } \\
\text { hospitalization }\end{array}$ \\
\hline
\end{tabular}

Giuli, C.

et al, 2012

Social isolation risk factors in older hospitalized individuals

Lee, $\mathrm{W}$. et al, 2012

Dose-dependent effect of rehabilitation in functional recovery of older patients in the post-acute care unit

Nägga, K. Health-related factors et al, 2012 associated with

hospitalization for old people: Comparisons of elderly aged 85 in a population cohort study

Ciro, C.A. Patterns and correlates of et al, 2012 depression in hospitalized older adults

Bryant, C., The role of physical and Jackson, $\mathrm{H}_{\text {., }}$ psychological variables in Ames, D,

2011 predicting the outcome of hospitalization in very old adults

\section{Study} Particularities

Archives of Gerontology and Geriatrics

\section{$\mathrm{N}=97$ (51 men) persons with a mean age of 75.3 (SD 6.3) years and Mini Mental State Evaluation (MMSE) score of 28.0 (SD 1.6)} participated.

Archives of Gerontology and Geriatrics

\section{Archives of}

Gerontology

and Geriatrics

Archives of

Gerontology

and Geriatrics

Out of 650 eligible individuals, 496 (78\% of those alive) participated.

Longitudinal study on 580 hospitalized elderly sample aged $\geq 70$.

$\mathrm{N}=458$ patients (mean age: $83.4 \pm 5.5$ years, all males) completed PAC services. physical and psychological function with pain reduction, which deserves further investigations to evaluate whether there is a ceiling effect of rehabilitative therapy in PAC services.

The non-hospitalized group reported a better health status than the hospitalized group in terms of medical aspects, living conditions and subjective estimation. Factors associated with in-patient care were an increased number of general practitioner visits, more assistive technology, community assistance, multimorbidity and/or diagnosed congestive heart failure and arrhythmia.

Archives of Gerontology and Geriatrics

Archives of Gerontology and Geriatrics
Included 197 patients aged 65 years or older hospitalized with an acute medical illness.

Consecutively admitted patients ( $n=100$, mean age 82 years) completed measures of health status, anxiety, depression, selfefficacy, personality and coping.
Patients with persistent depressive symptoms make up the majority of post-hospitalization depression cases. Post-hospitalization social support and daily living skills appear to be important in the management of follow-up depressive symptoms

The results suggest that in physically unwell, very old populations, physical health factors may be stronger predictors of functioning than psychological variables. The findings also highlight some difficulties in the use of psychological measures in old-old populations, and the need for more research that recognizes the oldest old as a distinct group. 


\begin{tabular}{|c|c|c|c|c|}
\hline Journal & Sample & $\begin{array}{l}\text { Study } \\
\text { Particularities }\end{array}$ & Study Particularities & Study Particularities \\
\hline $\begin{array}{l}\text { Weiland, M., } \\
\text { Dammer- } \\
\text { mann, C., } \\
\text { Stoppe, G. } \\
\quad 2011\end{array}$ & $\begin{array}{l}\text { Selective optimization } \\
\text { with compensation } \\
\text { (SOC) competencies in } \\
\text { depression }\end{array}$ & $\begin{array}{l}\text { Journal of } \\
\text { Affective } \\
\text { Disorders }\end{array}$ & $\begin{array}{l}\text { Fifty-three patients ( } 31 \text { women and } 22 \\
\text { men), aged } 21 \text { to } 73 \text { years. }\end{array}$ & $\begin{array}{l}\text { These findings support the hypothesis that the SOC ability is dynamic } \\
\text { and mood dependent (state effect). Otherwise, there is no hint of } \\
\text { life-long reduced SOC competencies or a trait effect which would } \\
\text { be associated with an increased vulnerability to the development of } \\
\text { a depressive disorder. Regarding the high prevalence of depression } \\
\text { especially in the elderly and physically ill patients, (gerontological) studies } \\
\text { on SOC competencies should take depression into account. }\end{array}$ \\
\hline $\begin{array}{l}\text { Chen, C.C.H. } \\
\text { et al, } 2011\end{array}$ & $\begin{array}{l}\text { Prevalence of geriatric } \\
\text { conditions: A hospital- } \\
\text { wide survey of } 455 \\
\text { geriatric inpatients in a } \\
\text { tertiary medical center }\end{array}$ & $\begin{array}{l}\text { Archives of } \\
\text { Gerontology } \\
\text { and Geriatrics }\end{array}$ & $\begin{array}{l}455 \text { inpatients, aged } 65 \text { and older, from } 24 \\
\text { medical and surgical units of a } 2200 \text {-bed } \\
\text { urban academic medical center in Taiwan. }\end{array}$ & $\begin{array}{l}\text { Furthermore, high rates of geriatric conditions indicate strong needs } \\
\text { for care that does not fit into traditional disease models of medicine. } \\
\text { Care should be better targeted to address different risks for geriatric } \\
\text { conditions of medical versus surgical geriatric inpatients in acute care } \\
\text { settings. }\end{array}$ \\
\hline $\begin{array}{l}\text { Jakobsson, U. } \\
\text { et al, } 2011\end{array}$ & $\begin{array}{l}\text { Psychosocial perspectives } \\
\text { on health care utilization } \\
\text { among frail elderly } \\
\text { people: An explorative } \\
\text { study }\end{array}$ & $\begin{array}{l}\text { Archives of } \\
\text { Gerontology } \\
\text { and Geriatrics }\end{array}$ & $\begin{array}{l}\text { Sixty-three people aged } 69-96 \text { years were } \\
\text { included in the study. }\end{array}$ & $\begin{array}{l}\text { Thus, older people whose health care consumption mainly comprises } \\
\text { outpatient care appeared to have the least impact on the psychosocial } \\
\text { variables (e.g., the highest life satisfaction, felt least lonely and were at } \\
\text { the lowest risk of depression). Thus, measures taken to prevent health } \\
\text { care utilization, especially among those with high utilization of inpatient } \\
\text { care, will most likely have a positive effect on psychosocial variables and } \\
\text { life satisfaction/quality of life (QoL) }\end{array}$ \\
\hline
\end{tabular}

McKenzie, Pessimism, worthlessness,

D.P. et al, anhedonia, and thoughts

2010 of death identify DSM-

IV major depression in

hospitalized, medically ill patients

Grewal, K. Timing of depressive

et al, 2010 symptom onset and in-

hospital complications

among acute coronary

Psychosomatics The present study provides a further analysis of 312 medically ill patients.

The identification of key symptoms, particularly those involving pessimism, may aid clinical understanding and treatment of depression

Psychosomatics A group of 906 ACS inpatients from 12 coronary-care units participated in the study.
Incident symptoms, in particular, seem to be prognostic. This finding suggests that acute emotions may be triggering cardiac complications, and early identification of emotional symptoms is warranted. 


\begin{tabular}{|c|c|c|c|c|}
\hline Journal & Sample & $\begin{array}{c}\text { Study } \\
\text { Particularities }\end{array}$ & Study Particularities & Study Particularities \\
\hline $\begin{array}{l}\text { Chang, H.H. } \\
\text { et al, } 2010\end{array}$ & $\begin{array}{l}\text { Outcomes of hospitalized } \\
\text { elderly patients with } \\
\text { geriatric syndrome: report } \\
\text { of a community hospital } \\
\text { reform plan in Taiwan. }\end{array}$ & $\begin{array}{l}\text { Archives of } \\
\text { Gerontology } \\
\text { and Geriatrics }\end{array}$ & $\begin{array}{l}\text { A prospective study involving patients } \\
\text { aged } 65 \text { years and older in } 12 \text { community } \\
\text { hospitals was performed. }\end{array}$ & $\begin{array}{l}\text { On multivariate analysis, older age, low mini mental state examination } \\
\text { (MMSE) score, and low MNA score were predictors of functional } \\
\text { deterioration. Under the interdisciplinary team care of the Community } \\
\text { Hospital Reform Plan (CHRP), most of the elderly patients maintained } \\
\text { or increased their functional capacity; the one-year mortality rate was } \\
\text { higher than that of the general population but lower than that of other } \\
\text { studies targeting the frail elderly. }\end{array}$ \\
\hline $\begin{array}{l}\text { Barca, M.L. } \\
\text { et al, } 2010\end{array}$ & $\begin{array}{l}\text { A } 12 \text { months follow- } \\
\text { up study of depression } \\
\text { among nursing-home } \\
\text { patients in Norway }\end{array}$ & $\begin{array}{l}\text { Journal of } \\
\text { Affective } \\
\text { Disorders }\end{array}$ & $\begin{array}{l}\text { A sample of } 902 \text { randomly selected } \\
\text { nursing-home patients was assessed using } \\
\text { the Cornell Scale, the Clinical Dementia } \\
\text { Rating Scale, the Self-Maintenance Scale } \\
\text { and a measurement of physical health. }\end{array}$ & $\begin{array}{l}\text { The incidence and persistence rates of clinical significant depressive } \\
\text { symptoms are high in nursing-home patients. A higher score on Cornell } \\
\text { Scale at baseline and a shorter stay in a nursing home were predictors } \\
\text { for both incidence and persistence of clinically significant depressive } \\
\text { symptoms. }\end{array}$ \\
\hline $\begin{array}{c}\text { Unsar, S., Sut, } \\
\text { N. } 2010\end{array}$ & $\begin{array}{l}\text { Depression and health } \\
\text { status in elderly } \\
\text { hospitalized patients with } \\
\text { chronic illness }\end{array}$ & $\begin{array}{l}\text { Archives of } \\
\text { Gerontology } \\
\text { and Geriatrics }\end{array}$ & $\begin{array}{l}\text { Conducted with } 100 \text { patients with a } \\
\text { chronic health problem who were } 60 \text { years } \\
\text { old or older. }\end{array}$ & $\begin{array}{l}\text { As the level of depression increased in chronically ill hospitalized elderly } \\
\text { patients their quality of life decreased. Providing of psychosocial support, } \\
\text { supplying of psychosocial needings, and improving of physical and } \\
\text { functional capacity will help for improve quality of life in chronically ill } \\
\text { elderly patients receiving medical treatment in the hospital }\end{array}$ \\
\hline $\begin{array}{l}\text { De Jonge, P. } \\
\text { et al, } 2009\end{array}$ & $\begin{array}{l}\text { Prevention of major } \\
\text { depression in complex } \\
\text { medically ill patients: } \\
\text { Preliminary results from } \\
\text { a randomized, controlled } \\
\text { trial }\end{array}$ & Psychosomatics & $\begin{array}{l}\text { Of } 247 \text { randomized patients, the authors } \\
\text { identified } 100 \text { patients with a high level of } \\
\text { case complexity at baseline and without } \\
\text { major depression ( } 65 \text { rheumatology } \\
\text { and } 35 \text { diabetes patients). Patients were } \\
\text { randomized to usual care }(N=53) \text { or to a } \\
\text { nurse-led intervention }(\mathrm{N}=47) \text {. }\end{array}$ & $\begin{array}{l}\text { These preliminary results based on subgroup analysis suggest that a } \\
\text { multifaceted nurse-led intervention may prevent the occurrence of } \\
\text { major depression in complex medically ill patients and reduce depressive } \\
\text { symptoms in diabetes outpatients. }\end{array}$ \\
\hline $\begin{array}{l}\text { Wong, S.Y. et } \\
\text { al, } 2009\end{array}$ & $\begin{array}{l}\text { The relationship between } \\
\text { clinically relevant } \\
\text { depressive symptoms and } \\
\text { episodes and duration of } \\
\text { all cause hospitalization in } \\
\text { Southern Chinese elderly }\end{array}$ & $\begin{array}{l}\text { Journal of } \\
\text { Affective } \\
\text { Disorders }\end{array}$ & $\begin{array}{l}\text { We administered the validated Chinese } \\
\text { version of Geriatric Depression Scale on } \\
3770 \text { men and women aged 65years and } \\
\text { over. }\end{array}$ & $\begin{array}{l}\text { It was shown that clinically relevant depressive symptoms are } \\
\text { independently associated with inpatient utilization over a } 4 \text {-year period } \\
\text { after adjustment for socioeconomic and health status in these elderly } \\
\text { subjects. Identification and effective management of depression in } \\
\text { primary care may be one way to reduce hospital service utilization in the } \\
\text { elderly in China. }\end{array}$ \\
\hline
\end{tabular}


anemia, sleep disturbance, dehydration, visual and hearing impairment $[3,14]$. This high prevalent syndrome is associated with morbidity and bad outcomes in hospitalized elderly patients, for being more vulnerable and more susceptible to severe health problems [9].

Both chronic diseases -solo or multi-morbidity, for Nagga et al (2012) [1]- and geriatric symptoms are linked to a higher hospital admission in this age group, other factors that may influence the high utilization of care, according to Jakobsson et al. (2011) [15], are female gender, unmarried or widows, living alone, cognition problems, physical functioning, poor financial situation, depression and poor selfrated health.

Unsar and Sut (2010) [4] studied the link between depression and health status in hospitalized elderly patients, as result he conclude that $64 \%$ of the aged patients experienced important depressive symptoms while in care. The depressive status is not only because of the hospitalization, it is a sum up of the diagnoses/diseases and related symptoms, corroborated by proven relation with cancer, circulatory system diseases, to mood changes and quality of life [15] and according to Nagga (2012) [1] is also justified by social status and health beliefs dimension.

\section{The depression post-hospitalization and its risk factors}

Depression is common in people aged 65 or more, considered as common as a chronic disease [3] being more prevalent in those hospitalized presenting with substantial increase of its symptoms and severity $[2,9]$. The patients more likely to present depressive symptoms are those with cognitive impairment, isolation from interpersonal communication, limited access to friends and family support, with geriatric conditions and in-hospital complications $[2,12,16]$.

The studies about the incidence of depression in institutionalized patients have a wide variation, from $1.6 \%$ to $19 \%$, with $50 \%$ of persistence after 6 to 12 months after hospital discharge according to Barca et al. (2010) [7]. To Chen et al. (2014) [17] following a prolonged stay, $48 \%$ of the patients were depressive by hospital discharge, even though occurred remission of the depression, almost 9\% of new cases developed 6 months after discharge. Ciro et al. (2012) [6] report that of the ones depressed at the follow up $81 \%$ were depressed at admission and $19 \%$ were new cases.

Depression is inwardly correlated with long hospital stay, poor quality of life and decline in the performance of the activities of daily living [5]. The best predictor of outcome is physical health status on admission to hospital [13]. It is stated that in-hospital depression draw to poorer longterm prognosis [16], but not much is known of its predictors or impacts of interventions during hospitalization [2].

To Chen et al. (2014) [17] there is four major factors associated to baseline depressive symptoms: social support, cognitive status, functional dependence and nutritional status, they predict the symptomatology over the hospitalization time. Poor physical health is an important predictor of the incidence of depression [7].

The depressive disorder is multifaceted in its clinical presentation, as general signs there are body weight loss, memory impairment, exacerbate disabilities and symptoms of chronic diseases [8], as psychopathological signs there are difficulty in decision making, feeling of loneliness, fear of illness, becoming dependent, an uncertain future, untidy appearance, psychomotor agitation/slowness, anxiety pathological guilt, delusions, mood states - demoralization (hopelessness/helplessness) and anhedonia, autonomic anxiety and somatoform symptoms $[1,10,11]$.

According to McKenzie et al. (2010) [11] major depression can be difficult to diagnose in medically ill patients, two combinations of symptoms where highly associated with it, one is pessimism and wor- 
thlessness, the other is pessimism, loss of interest in others and thoughts of death.

Early identification is necessary to prevent the progress or deterioration of the depression, also is needed to be cautious whether health interventions to other patient issues may consequence of worsening the depressive symptoms [2]. This kind of depression has a dynamic nature dependent of its time-points: admission, discharge and post-discharge; being necessary to identify the vulnerable patients to post-hospital depression and treat modifiable risk factors [6].

The identified risk factors of the elderly to develop depression after hospitalization is: patients who are female, white, unmarried, or who had lower social support, higher daily living activities impairments and lower level of education $[2,6]$. Although most of the studies shows women at a higher risk, many others points to male patients at a higher risk at the admission, indicating that men have greater difficult to adjust/adapt to being unwell in the hospital ambience [2].

Patients with lack of folic acid tend to have more depressive symptoms, than those with adequate nutritional status, thus supplementation with folic acid and vitamin B12 has been shown to improve mood in patients with major depression [17].

\section{Depression and its consequences in the hospitalized elderly}

The acute state of depression is correlated with inhospital complications, especially proven by a study of Grewal et al. (2010) [16] with cardiac patients; those patients had two times more risk than the non-depressive ones. Although it's been alerted to have a tighter control with these findings, previous studies did not find significance over mortality [7, 16]. Other studies agree that depressive symptoms are a major risk factor for long-term disability and mortality in older patients [13, 17].

For Bryant et al. (2011) [13] the worsening of depression was associated with a poorer ability to perform the basic activities of daily living and higher number of physical health problems, this being a high prevalent and persistent state in the elderly (the more severe symptoms the more chances to persist it). Although depression is highly prevalent, in this same study, did not predict a bad outcome, the symptoms represented an acute psychological response to being admitted to hospital rather than an enduring mental state.

Some of the negative effects of those depressive symptoms are hardened recovery from illness, increased use of health care services and expenses, poorer patient compliance, cooperation with treatment, quality of life, smaller response to treatment, bad prognosis and morbidity [4]. According to Chang et al. (2010) [14] the predictors of functional deterioration were older age, high baseline functional capacity, poorer cognitive function, and poorer nutritional status.

\section{Follow-up of discharged elderly patients}

Some modifiable risk factors at follow up as lack of social support and limitations in activities of daily living, predict post-hospitalization depression [6]. Generally, the clinically important symptoms of depression persist through to discharge [2], resulting in poor treatment adherence and hospital readmission.

Although it exist a decrease at the prevalence of depression between hospitalized patients and the discharged ones; it is proven the necessity of closer assessment of depressive symptoms in hospital and structured mental health care after discharge.

\section{Treatment and prevention of depression post-hospitalization}

The treatment of elderly individuals should help them to stay mentally, physically and socially wellfunctioning, if properly applied, and maximizing the probability of success, their quality of life can have great increase [4]. It is necessary to use screening measures of cognitive function and emotional 
health when planning care for older patients after hospitalization [5], because depressive symptoms are often unrecognized and under-treated in older adult populations [6, 18].

To Nagga et al. (2012) [1] the guiding principle in eldercare is, for those individuals, to remain in their own homes for as long as possible, but it still difficult to know how to monitor them, who were possibly frailer or paradoxically healthier but with a depressed mental state. Already in the hospital it is important to have appropriate nursing care with effective communication inclusion of the patient and family in the care plan, delivery information to the patient before treatment and nursing care, and psychosocial support, this can result in a decreased depression [4].

There is yet no evidence that treating elevated symptoms of depression results in better outcomes in the long-term [16]. The use of antidepressants is a predictor for worsening of depressive symptoms in patients, such as sadness, irritability, psychomotor retardation, weight loss, loss of appetite and difficulty falling asleep worsened significantly in patients using antidepressants during the follow-up period [7].

The much known 'prescribing cascade' is a problem, to the elderly a medication can result in an adverse drug event, that is mistaken for a separate condition and treated with more medications, with more risks for another adverse event [3]. The symptoms that deserve more attention are dehydration, depression, anemia, deprived sensorial, pain, immobilization and incontinence. For its prevention it has been developed the STOPP strategy (screening tool of older person's potentially inappropriate prescriptions) that encourages clinicians to consider medications as a probable cause of symptoms, avoiding unnecessary prescribing cascades and paying more attention to screening it.

Post-hospitalization social support and daily living skills appear to be important in managing the follow-up of depressive symptoms. The primary prevention of depression must consider case complexity, comorbidities, psychosocial vulnerability to include the patients in a depression prevention program [19].

New proposals with interdisciplinary team care for the approach to the older patients with depression include:

a) Intensified rehabilitation therapy to improve physical function, depressive symptoms and pain [12].

b) Target the triad of depressive symptoms, functional dependence, and nutritional status- multimodal intervention with necessary pharmacological therapy to orient communication, early ambulation and nutritional assistance [3].

c) Comprehensive geriatric assessment (CGA)multiple problems of older persons are described and explained, the resources and strengths of the person are cataloged, need for services assessed, and a coordinated care plan developed [3].

d) Antidepressant medication only for severe depressions.

e) Chronic disease self-management programsmake use of models of problem-solving and cognitive behavioral strategies, indicating that coping strategies can be strengthened and the development of depression prevented [18].

f) Education programs for the medical team and families of the patients.

\section{Conclusion}

Older patients tend to present symptoms of depression when hospitalized. Elevated levels of depressive symptoms are associated with bad treatment adhesion, longer stays, more hospital readmissions, and reduced functional status.

Depression in older patients is most of the times unrecognized and undertreated, so the key 
to prevent the depressive symptoms -during hospitalization and post-discharge- is to know and treat its modifiable predictors. The risk factors that can predict those symptoms are chronic diseases, geriatric symptoms, lower social support, higher daily living activities impairments and lower level of education.

Our review highlights the importance of depressive symptoms in elderly patients and the necessity to treat it, new approaches with proven capability were enumerated, but it is still needed further investigation to test the effects of these preventive and therapeutics lines in larger samples.

\section{References}

1. Nägga K, Dong H-, Marcusson J, Skoglund SO, Wressle E. Health-related factors associated with hospitalization for old people: Comparisons of elderly aged 85 in a population cohort study. Arch Gerontol Geriatr [Internet]. 2012; 54(2): 391-7. Available from: www.scopus.com

2. Haines TP, Williams CM, Hill A-, McPhail SM, Hill D, Brauer SG, Hoffmann TC, Etherton-Beer C. Depressive symptoms and adverse outcomes from hospitalization in older adults: Secondary outcomes of a trial of falls prevention education. Arch Gerontol Geriatr [Internet]. 2015; 60(1): 96-102. Available from: www.scopus.com

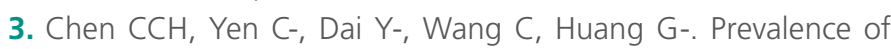
geriatric conditions: A hospital-wide survey of 455 geriatric inpatients in a tertiary medical center. Arch Gerontol Geriatr [Internet]. 2011; 53(1): 46-50. Available from: www.scopus.com

4. Unsar S, Sut N. Depression and health status in elderly hospitalized patients with chronic illness. Arch Gerontol Geriatr [Internet]. 2010; 50(1): 6-10. Available from: www.scopus.com

5. Helvik A-, Selbæk G, Engedal K. Functional decline in older adults one year after hospitalization. Arch Gerontol Geriatr [Internet]. 2013; 57(3): 305-10. Available from: www.scopus.com

6. Ciro CA, Ottenbacher KJ, Graham JE, Fisher S, Berges I, Ostir GV. Patterns and correlates of depression in hospitalized older adults. Arch Gerontol Geriatr [Internet]. 2012; 54(1): 202-5. Available from: www.scopus.com
7. Barca ML, Engedal K, Laks J, Selbaek G. A 12 months follow-up study of depression among nursing-home patients in norway. J Affect Disord [Internet]. 2010; 120(1-3): 141-8. Available from: www.scopus.com

8. Wong SY, Mercer SM, Leung J, Woo J. The relationship between clinically relevant depressive symptoms and episodes and duration of all cause hospitalization in southern chinese elderly. J Affect Disord [Internet]. 2009; 113(3): 272-8. Available from: www.scopus.com

9. Helvik A-, Engedal K, Selbæk G. Change in sense of coherence (SOC) and symptoms of depression among old non-demented persons 12 months after hospitalization. Arch Gerontol Geriatr [Internet]. 2013; 56(2): 314-20. Available from: www.scopus.com

10. Wilkowska-Chmielewska J, Szelenberger W, Wojnar M. Agedependent symptomatology of depression in hospitalized patients and its implications for DSM-5. J Affect Disord [Internet]. 2013; 150(1): 142-5. Available from: www.scopus.com

11. McKenzie DP, Clarke DM, Forbes AB, Sim MR. Pessimism, worthlessness, anhedonia, and thoughts of death identify DSM-IV major depression in hospitalized, medically ill patients. Psychosomatics [Internet]. 2010; 51(4): 302-11. Available from: www.scopus.com

12. Lee W-, Cheng Y-, Liu C-, Peng L-, Liu L-, Chen L-. Dose-dependent effect of rehabilitation in functional recovery of older patients in the post-acute care unit. Arch Gerontol Geriatr [Internet]. 2012; 54(3): e290-3. Available from: www.scopus.com

13. Bryant C, Jackson $H$, Ames D. The role of physical and psychological variables in predicting the outcome of hospitalization in very old adults. Arch Gerontol Geriatr [Internet]. 2011; 53(2): 146-51. Available from: www.scopus.com

14. Chang HH, Tsai SL, Chen CY, Liu WJ. Outcomes of hospitalized elderly patients with geriatric syndrome: Report of a community hospital reform plan in taiwan. Arch Gerontol Geriatr [Internet]. 2010; 50 Suppl 1: S30-33. Available from: www.scopus.com

15. Jakobsson U, Kristensson J, Hallberg IR, Midlöv P. Psychosocial perspectives on health care utilization among frail elderly people: An explorative study. Arch Gerontol Geriatr [Internet]. 2011; 52(3): 290-4. Available from: www.scopus.com

16. Grewal K, Stewart DE, Abbey SE, Leung YW, Irvine J, Grace SL. Timing of depressive symptom onset and in-hospital complications among acute coronary syndrome inpatients. Psychosomatics [Internet]. 2010; 51(4): 283-8. Available from: www.scopus.com 
17. Chen C-, Huang G-, Chen CCH. Older patients' depressive symptoms 6 months after prolonged hospitalization: Course and interrelationships with major associated factors. Arch Gerontol Geriatr [Internet]. 2014; 58(3): 339-43. Available from: www.scopus.com

18. Weiland M, Dammermann C, Stoppe G. Selective optimization with compensation (SOC) competencies in depression. J Affect Disord [Internet]. 2011; 133(1-2): 114-9. Available from: www.scopus.com

19. De Jonge P, Bel Hadj F, Boffa D, Zdrojewski C, Dorogi $Y$, So A, Ruiz J, Stiefel F. Prevention of major depression in complex medically ill patients: Preliminary results from a randomized, controlled trial. Psychosomatics [Internet]. 2009; 50(3): 227-33. Available from: www.scopus.com

20. Giuli, C., Spazzafumo, L., Sirolla, C., Lattanzio, F., Postacchini, D. Social isolation risk factors in older hospitalized individuals. Arch Gerontol Geriatr [Internet]. 2012. Available from: www.scopus.com

\section{Comment on this article:}

\section{(f) $B$ in $8+\mathbf{S} \rho$}

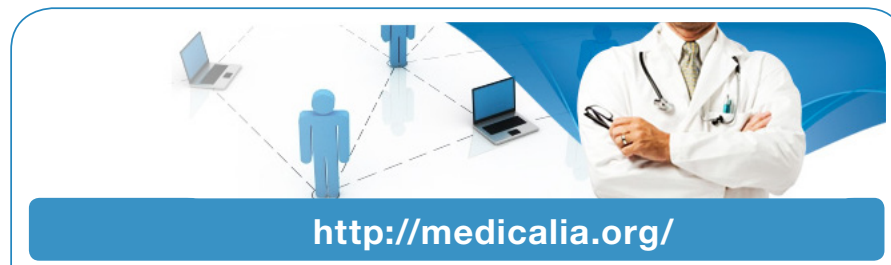

Where Doctors exchange clinical experiences, review their cases and share clinical knowledge. You can also access lots of medical publications for free. Join Now!

\section{Publish with iMedPub}

http://www.imed.pub

International Archives of Medicine is an open access journal publishing articles encompassing all aspects of medical science and clinical practice. IAM is considered a megajournal with independent sections on all areas of medicine. IAM is a really international journal with authors and board members from all around the world. The journal is widely indexed and classified Q1 in category Medicine. 